\title{
A fast drying method for the production of salted-and-dried meat
}

\author{
Marlene BAMPI ${ }^{1 \star}$ (D), Franciny Campos SCHMIDT², João Borges LAURINDO³
}

\begin{abstract}
The objective of this work was to investigate the application of microwave vacuum drying (MWVD) as a fast drying method to produce salted-and-dried beef cuts. Moreover, aiming to reduce the sodium content in the meat product, the partial replacement of $\mathrm{NaCl}$ by $\mathrm{KCl}$ during the salting stage was also investigated. To this end, beef cuts were salted by immersion in one of three saline solutions before drying: Solution A- $100 \% \mathrm{NaCl}$; Solution B- $75 \% \mathrm{NaCl}$ and $25 \% \mathrm{KCl}$; and (iii) Solution C- $50 \% \mathrm{NaCl}$ and $50 \% \mathrm{KCl}$. The proposed MWVD method was compared with convective drying (CD) and vacuum drying (VD) in terms of drying kinetics as well as physicochemical and mechanical properties of obtained samples. The average drying times for the samples to reach water activity of 0.7 was more than $40 \mathrm{~h}$ for $\mathrm{CD}, 36 \mathrm{~h}$ for VD, and $0.45 \mathrm{~h}$ for MWVD. The salting with different solutions had no influence in these times. Moreover, the MWVD samples presented higher values of porosity and rehydration capacity. Thus, the results presented in this study have technological importance for the design of new industrial technologies to produce salted-and-dried meat, as charque and jerked beef, with lower sodium content.
\end{abstract}

Keywords: microwave vacuum drying; sodium replacement; charque; jerked beef.

Practical Application: The knowledge of how the different drying methods and the partial replacement of $\mathrm{NaCl}$ by $\mathrm{KCl}$ influence the physicochemical characteristics and mechanical properties is of great importance for the production of salted-and-dried meat.

\section{Introduction}

Salted-and-dried meat products are popular in many countries due to their appreciated sensory characteristics (Collignan et al., 2001; Arnau et al., 2007; Toldrá, 2016). Examples of these products are the charque (a traditional Brazilian meat product) and the jerked beef (which differs from the charque mainly by the use of sodium nitrite) (Shimokomaki et al., 1998; Ojha et al., 2017). The Brazilian legislation establishes that charque must contain at most $47,25 \%$ of moisture and $15 \%$ of mineral matter (Shimokomaki et al., 1998), whereas jerked beef must contain at most $55 \%$ of moisture, $18.3 \%$ of mineral matter, and maximum water activity of 0.78 (Brasil, 2000). In spite of being partially desalted before meal preparation, the consumption of these products still results in a high sodium intake, which has been associated to chronic diseases such as hypertension, cardiovascular diseases, stroke, and renal illnesses (Albarracín et al., 2011; Barat et al., 2012). As a result, a considerable research effort has been dedicated to reduce the total salt content $(\mathrm{NaCl})$ in such products as well as the replacement of $\mathrm{NaCl}$ by other chloride salts ( $\mathrm{KCl}, \mathrm{CaCl}_{2}$, and $\mathrm{MgCl}_{2}$ ), non-chloride salts (phosphates), or even a combination of both (Aliño et al., 2010; Mcgough et al., 2012; Bampi et al., 2016a).

The charque manufacturing is still largely based on handmade and time consuming processes, involving long stages of salting and solar drying (from 5 to 6 days, at least) (Shimokomaki et al., 1998). On the other hand, the most used drying method for jerked beef production is convective drying (Ratti, 2001; Chen
\& Mujumdar, 2008). However, the hot air circulation involved in convective drying often give rise to a superficial dryness of the product, which makes difficult the moisture evaporation and reduces the drying rate (Muñoz et al., 2012). Moreover, the convective drying at high temperatures may cause denaturation of the proteins and modify the sensory properties of the product (Bampi et al., 2016a).

Many alternative techniques have been developed aiming to reduce the drying time and improve the quality of different dehydrated food products. These techniques include vacuum drying, freeze-drying, and the use of dielectric heating sources, such as microwaves (Jangam et al., 2010; Manafzadeh et al., 2013). In the case of vacuum drying, the removal of moisture from the product occurs typically at pressures below $20-30 \mathrm{kPa}$, and consequently at temperatures lower than $60-70^{\circ} \mathrm{C}$ (Jangam, 2011; Foerst \& Kulozik, 2007). This process is suitable for dehydration of heat-sensitive foods or products that exhibit oxidative properties (Jangam, 2011). In the drying process using microwaves, heat is generated volumetrically in wet materials by a combination of polarization mechanism due to the dipole rotation (oscillations) and ionic conduction. The main advantages of microwave drying are: i) short drying time, ii) more uniform heating, iii) good energy efficiency (almost all electromagnetic energy is converted into heat), iv) improved product quality, and v) flexibility in the production of a wide variety of products (Haghi \& Amanifard, 2008; Monteiro et al., 2015). The microwave 
energy can be combined with vacuum, which can, in many cases, result in products with properties comparable to those of freeze dried products, but in much shorter times and with lower costs (Monteiro et al., 2015).

In this context, the objective of this work was to evaluate the influence microwave vacuum drying (MWVD) on the drying kinetics and also on the physicochemical characteristics and mechanical properties of beef cuts salted using brines with partial replacement of $\mathrm{NaCl}$ by $\mathrm{KCl}$. The proposed MWVD method was compared with convective drying (CD) and vacuum drying (VD).

\section{Material and methods}

\subsection{Samples preparation}

The beef cuts (chuck) used in this study were purchased in a local market in Florianópolis, SC, Brazil. Only muscles with $\mathrm{pH}$ between 5.40 and 5.90 were used. For the salting stage, the samples were cut in the form of parallelepipeds with dimensions of $8.0 \times 8.0 \times 1.5 \mathrm{~cm}$ (length $\times$ width $\times$ thickness $)$ and weight of about $150 \mathrm{~g}$.

The samples were salted by immersion using one of the three following saline solutions: Solution A with $100 \% \mathrm{NaCl}$ $\left(\approx 6 \mathrm{~mol} \mathrm{NaCl} \mathrm{L}{ }^{-1}\right)$, Solution B with $75 \% \mathrm{NaCl}$ and $25 \% \mathrm{KCl}$ $\left(\approx 4.5 \mathrm{~mol} \mathrm{NaCl} \mathrm{L}^{-1}\right.$ and $\left.1.5 \mathrm{~mol} \mathrm{KCl} \mathrm{L}^{-1}\right)$ and Solution $\mathrm{C}$ with $50 \% \mathrm{NaCl}$ and $50 \% \mathrm{KCl}\left(\approx 3 \mathrm{~mol} \mathrm{NaCl} \mathrm{L}{ }^{-1}\right.$ and $\left.3 \mathrm{~mol} \mathrm{KCl} \mathrm{L}^{-1}\right)$. The salting stage was performed at $10^{\circ} \mathrm{C}$ with three vacuum pulses of $7 \mathrm{kPa}$ for 5 minutes followed by around 2 minutes at atmospheric pressure (totalizing approximately 20 minutes of process), as described by Bampi et al. (2016b). The salting time was based on a previous study, aiming to obtain an average total

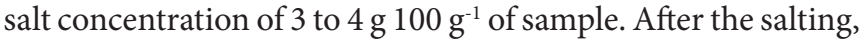
the cuts were stored at $10^{\circ} \mathrm{C}$ for 48 hours for homogenizing the salt concentration. The time of homogenization of the salt in the samples was established based on a previous study, in which three different regions (surface, center and intermediate region between the surface and the center) of the samples were analyzed after $48 \mathrm{~h}$, confirming the homogeneity of the salt concentration in the sample. Then, the samples were cut in four equal parts with dimensions of $4.0 \times 4.0 \times 1.5 \mathrm{~cm}$ (approximately $30 \mathrm{~g}$ ), labeled, and submitted to one of the following drying methods: (i) convective drying (CD), (ii) vacuum drying (VD), and (iii) microwave vacuum drying (MWVD).

\subsection{Drying devices and methodology}

For the CD, the salted samples were placed on a perforated plate inside a convective oven (TECNAL, model TE 394/2, Piracicaba, SP, Brazil) at $40^{\circ} \mathrm{C}$ (to avoid protein denaturation), with air circulating at $1 \mathrm{~m} \mathrm{~s}^{-1}$ (measured by Anemometer TESTO 425 , Germany), and air relative humidity of $30 \%$ (measured by ThermoHygrometer, TESTO 610, Germany).

The VD was performed in a vacuum chamber of $100 \mathrm{~L}$ (Ethik technology, model 440-OF, Brazil) connected to a vapor condenser and a vacuum pump with capacity of $350 \mathrm{~m}^{3} \mathrm{~h}^{-1}$ (DVP, model LC.305, San Pietro in Casale, BO, Italy). The chamber pressure was monitored using a digital vacuum gauge (Welch, Multi-range Vacuum Gauge PIZA 111, Fürstenfeldbruck,
Germany). The temperature of the drying chamber plates was kept at $40{ }^{\circ} \mathrm{C}$ by electric resistances, controlled by a proportional-integral-derivative (PID) controller (Novus, model N480D, Campinas, SP, Brazil). The temperature of the samples was monitored using T-type thermocouples (Iope, model TF-TX-A-TF-R30AWG, São Paulo, SP, Brazil) connected to a data acquisition system (Agilent Technologies, model 34970A, Santa Clara, CA, USA). To perform the VD, salted beef cuts were placed on the heated plates covered with polyester film (to prevent beef adhesion to the metal plates) and put inside the drying chamber. Thermocouples were inserted into the samples (in the geometric center), and the chamber pressure was reduced to $1.4 \mathrm{kPa}$ and kept at this condition during drying.

MWVD of salted beef cuts was performed in an adapted domestic microwave oven of 45 L (Electrolux, model MEX55, Stockholm, Sweden), with nominal power of $1000 \mathrm{~W}$ and frequency of $2.45 \mathrm{GHz}$. A cylindrical polypropylene recipient was installed inside the oven, and used as a vacuum chamber. This chamber was connected to a vacuum a pump with a flow rate of $350 \mathrm{~m}^{3} \mathrm{~h}^{-1}$ (DVP, model LC.305, San Pietro in Casale, BO, Italy) and the system pressure was monitored using a pressure transmitter (Wärme Brazil, model WTP-4010, Itaquaquecetuba, SP, Brazil). A silica gel column was installed between the chamber and vacuum pump for adsorption of the water vapor released during drying. A rotary system composed of a T-valve was used to rotate the vacuum chamber with the turntable, thereby leading to a more homogeneous absorption of microwaves by the samples. Figure 1 shows a schematic of the experimental device (a detailed description can be found in Monteiro et al., 2015). MWVD was performed with a nominal power of $300 \mathrm{~W}$. This power was chosen from preliminary tests with water, in which the water temperature did not exceed $40^{\circ} \mathrm{C}$.

The system pressure was kept near $5.3 \mathrm{kPa}$. At the end of the drying process, a digital thermometer (Incoterm, Porto Alegre, RS, Brazil) was used to measure the temperature of the samples.

All drying methods evaluated were performed in triplicate and until the samples reached $a_{w}$ values of approximately 0.7 . For each repetition, three samples were removed in predefined times for determining their moisture and $a_{w}$. For both CD and VD methods, samples were removed after each hour during the first

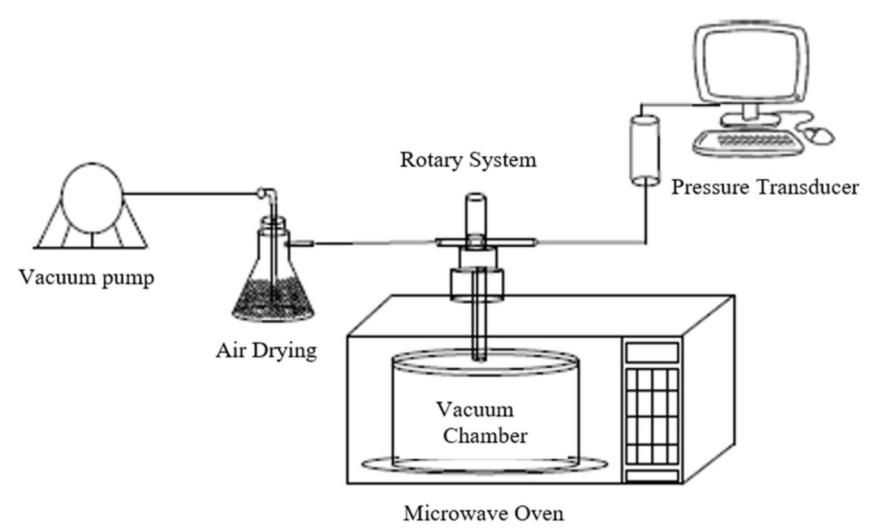

Figure 1. Sketch of the microwave vacuum drying device. Source: Monteiro et al. (2015). 
12 hours, after each two hours during the 12 subsequent hours, and after each 4 hours during the remaining time. During the MWVD process, samples were removed at every three minutes (by breaking the vacuum).

\subsection{Characterization of salted-and-dried beef cuts}

\section{Analytical determinations}

The moisture content of the beef cuts salted and dehydrated (previously ground and homogenized) was determined by oven drying until constant weight at $105^{\circ} \mathrm{C}$, according to the AOAC method 950.46 (Association of Official Analytical Chemists, 2007). The water activity $\left(a_{w}\right)$ was measured with a dew-point hygrometer (Decagon Devices Inc., Aqualab Model Series 3, Pullman, USA). The $\mathrm{pH}$ was measured using a digital potentiometer with electrode for solids (Analion, model PH-730, Ribeirão Preto, SP, Brazil). The color parameters at the surface of the meat cuts were measured using a MiniScan colorimeter (HunterLab, model EZ, Reston, VA, USA), which measures the visible spectrum with wavelengths ranging from $400 \mathrm{~nm}$ to $700 \mathrm{~nm}$. The CIELAB coordinate system (defined by CIE - Commission Internationale $d^{\prime}$ Eclairage) $\mathrm{L}^{*}$ (whiteness/darkness), $\mathrm{a}^{*}$ (greenness/redness), $\mathrm{b}^{*}$ (blueness/yellowness) with $10^{\circ}$ observer and illuminant D65 was used. The color difference $\left(\Delta \mathrm{E}^{\star}\right)$ was calculated using as reference the color of salted samples before drying.

The concentration of chloride ions $\left(\mathrm{Cl}^{-}\right)$was determined using $2 \mathrm{~g}$ of sample ground e homogenized in an Ultra-Turrax (IKA, Ultra-Turrax T25, Königswinter, Germany) at $700 \mathrm{~g}$ for $3 \mathrm{~min}$, with distilled water $(200 \mathrm{~mL})$. The suspension was centrifuged (Sigma, model 4k15, Osterode, Germany) at 16,000 g for $10 \mathrm{~min}$, and an aliquot of $500 \mu \mathrm{L}$ from the supernatant was analyzed using a chloride analyzer (Cole Parmer, Chloride Analyzer 926, Vernon Hills, IL, USA). The concentrations of sodium $\left(\mathrm{Na}^{+}\right)$and potassium $\left(\mathrm{K}^{+}\right)$ions were determined according to the Adolfo Lutz method 200/IV (Instituto Adolfo Lutz, 2008). Standard calibration curves for $\mathrm{NaCl}$ and $\mathrm{KCl}$ solutions, at concentrations of $1,2,5$ and $10 \mathrm{mg} \mathrm{L}^{-1}$, were prepared before using a flame photometer equipped with interferential filters (Micronal, model B462, São Paulo, SP, Brazil) for the determinations of the ion concentrations in the meat samples.

\section{Porosity}

The porosity $(\varepsilon)$ of the meat samples was determined from the true and apparent volumes of the samples, according Equation (1).

$\varepsilon=\left(1-\frac{V_{t}}{V_{a}}\right) \times 100$

where $\varepsilon$ is the porosity, $V_{t}$ is the true volume and $V_{a}$ represent the apparent volume of the beef samples.

The apparent volume $\left(V_{a}\right)$ was determined by the volume displaced by the sample when immersed in $n$-heptane, according to Lozano et al. (1983). The true volume $\left(V_{t}\right)$ of the beef samples was measured with a gas pycnometer (a more detailed description is available in Sereno et al., 2007). The mean of nine measured values was considered for each evaluated condition.

\section{Microstructure analysis}

The microstructure analyses of the samples were carried out by scanning electron microscopy (SEM). To this end, the meat samples were freeze-dried (in order to remove the residual moisture) and coated with gold using an anion-sputtering apparatus (Leica Microsystems, Leica EM SCD500, Wetzlar, Germany). The analyses were performed using a scanning electron microscope (JEOL, JSM 6390LV, Tokyo, Japan) operating at $10 \mathrm{kV}$.

\section{Rehydration capacity}

Aiming evaluate to influence of the drying methods on rehydration capacity (RC) of dehydrated beef cuts, samples with dimensions of $3.0 \times 3.0 \times 10 \mathrm{~cm}$ (width $\times$ length $\times$ thickness) with about $20 \mathrm{~g}$ were fully immersed in distilled water at $10^{\circ} \mathrm{C}$ for 24 hours. A beef to solution ratio of $0.1 \mathrm{~g} \mathrm{~mL}^{-1}$ was used. The sample rehydration capacity $\left(\mathrm{g} \mathrm{H}_{2} \mathrm{O} \mathrm{g}^{-1}\right.$ sample) was calculated using Equation (2), according to Nathakaranakule et al. (2007).

rehydration capacity $(\%)=\frac{M_{t}-M_{d}}{M_{d}} \times 100$

where $M_{t}$ is the mass of the rehydrated sample at time $t$ and $M_{d}$ is the mass of dried sample. The mean of nine values measured for each drying method evaluated was considered for statistical analysis.

\section{Mechanical properties}

For mechanical essays, salted and salted-and-dried beef samples (parallelepipeds with dimensions of $2.0 \times 2.0 \times 1.0 \mathrm{~cm}$ ) were cooked for 15 minutes in boiling water, cooled, and maintained at $5{ }^{\circ} \mathrm{C}$ until testing. The samples were submitted to shear force test and texture profile analysis (TPA) using a texturometer (Stable Micro Systems Texture Analyser TA-XT2i, England) equipped with a load cell of $250 \mathrm{~N}$. The force required to cut the sample was determined using a Warner-Bratzler shear (WB), with a speed of $5 \mathrm{~mm} \mathrm{~s}^{-1}$. The WB shear force was measured perpendicularly to the orientation of the muscle fibers. For the texture profile analysis (TPA), the samples were compressed twice with a 50\% compression ratio using a $50 \mathrm{~mm}$ circular flat probe with a crosshead speed of $1 \mathrm{~mm} \mathrm{~s}^{-1}$ (Huidobro et al., 2005; Schmidt et al., 2010). For the WB and TPA analyses, the mean of nine measured values was considered for each evaluated condition.

\subsection{Statistical analysis}

The results were evaluated by simple analysis of variance (ANOVA by one-way) with probability level of $95 \%$. For evaluating the significance of the differences between data $(\mathrm{p}<0.05)$, the means were compared by the Tukey test using the software Statistica ${ }^{\circledR} 7.0$ (StatSoft, Tulsa, USA).

\section{Results and discussion}

\subsection{Physicochemical and color parameters of salted beef cuts}

The average values of moisture content, $a_{w}, \mathrm{pH}$, salt content, and color parameters of salted beef obtained using different saline solutions are presented in Table 1 . The values of moisture and 
Table 1. Physicochemical and color parameters of salted beef cuts obtained using different saline solutions (Solution A: $100 \% \mathrm{NaCl}$, Solution B: $75 \% \mathrm{NaCl}+25 \% \mathrm{KCl}$, and Solution C: $50 \% \mathrm{NaCl}+50 \% \mathrm{KCl})(\mathrm{n}=9)$.

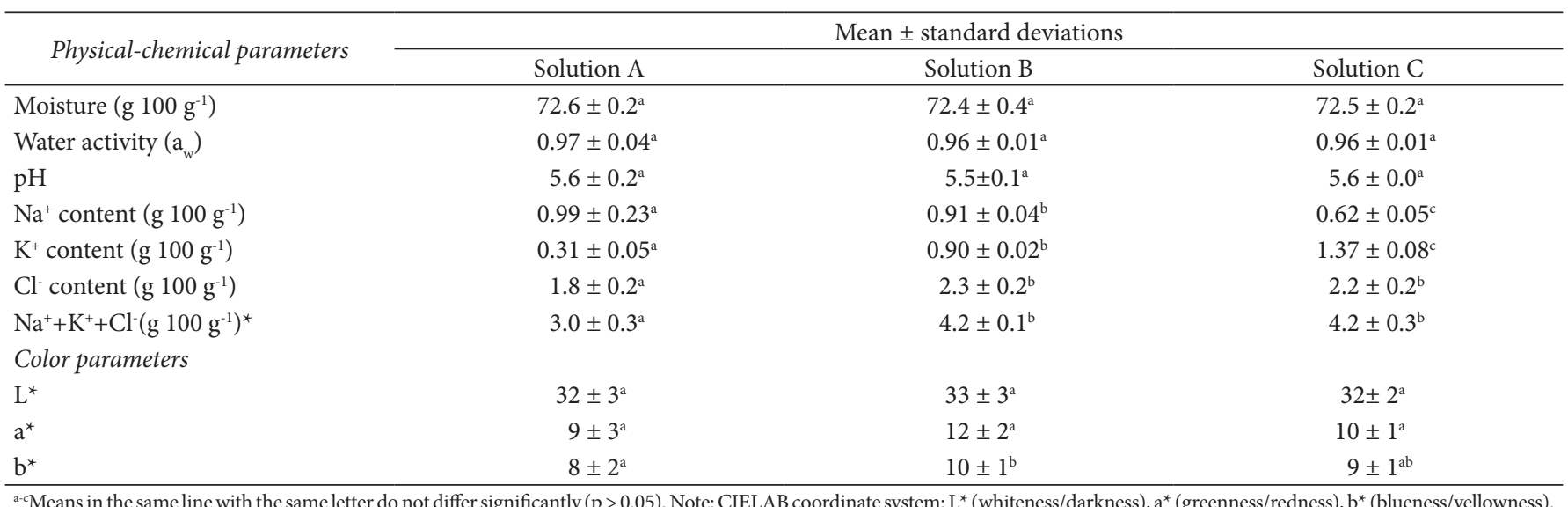

${ }^{a-c}$ Means in the same line with the same letter do not differ significantly $(\mathrm{p}>0.05)$. Note: CIELAB coordinate system: $\mathrm{L}^{\star}$ (whiteness/darkness), $\mathrm{a}^{\star}$ (greenness/redness), $\mathrm{b}^{\star}(\mathrm{blueness/yellowness)}$.

$a_{w}$ observed for the salted beef are still high enough to inhibit the development of deteriorating microorganisms, which demonstrates the high perishability of the product and the importance of combining complementary processes to extend the shelf life of salted meat products. The samples treated with Solution B $(75 \% \mathrm{NaCl}+25 \% \mathrm{KCl})$ and $\mathrm{C}(50 \% \mathrm{NaCl}+50 \% \mathrm{KCl})$ presented higher ion concentrations $\left(\mathrm{Na}^{+}+\mathrm{K}^{+}+\mathrm{Cl}\right)$ than those treated using Solution $\mathrm{A}(100 \% \mathrm{NaCL})$, due to more intake of $\mathrm{K}^{+}$ions than of $\mathrm{Na}^{+}$ions (Bampi et al., 2016b).

The lower concentration of $\mathrm{Cl}^{-}$ions observed in the samples salted using Solution A can be attributed to the strong interaction of $\mathrm{Na}^{+}$ions with meat proteins in the outer layers of the meat cuts, causing a compression of the myofibrils and thus hindering the penetration of $\mathrm{Cl}^{-}$ions. Since the $\mathrm{K}^{+}$ions have a lower charge density when compared to $\mathrm{Na}^{+}$ions, there is a smaller electrostatic interaction of $\mathrm{K}^{+}$with meat proteins (Barat et al., 2011).

\subsection{Drying kinetics of salted beef cuts}

Drying curves of salted beef cuts submitted to convective drying (CD), vacuum drying (VD), and microwave vacuum drying (MWVD) are shown in Figure 2a. Only one representative experimental curve is shown for each drying method, aiming to facilitate the comparison among them. The drying curves of the salted samples submitted to CD and VD presented similar behavior, with two different drying rate periods. In the first period ( 0 to $12 \mathrm{~h}$ ), a constant drying rate was observed, which allows an approximation by a straight line (see Figure 2a). Afterwards, a falling drying rate period (12 to $40 \mathrm{~h}$ ) was observed. As expected, VD tends to be faster than CD method. On the other hand, MWVD method showed only the constant drying rate period, which can be seen in the detail (zoom) inserted in Figure 2a. Twenty-two and fourteen hours were necessary to reduce the samples moisture from 2.5 to $1.25 \mathrm{~g} \mathrm{~g}^{-1}$ (dry basis) by CD and VD, respectively. MWVD needed only 18 minutes to yield the same moisture reduction, due to the conversion of the microwave energy into thermal energy, which accelerates the evaporation. In contrast, $\mathrm{CD}$ and VD depend on the heat transfer by conduction, thermal radiation, and in the case of
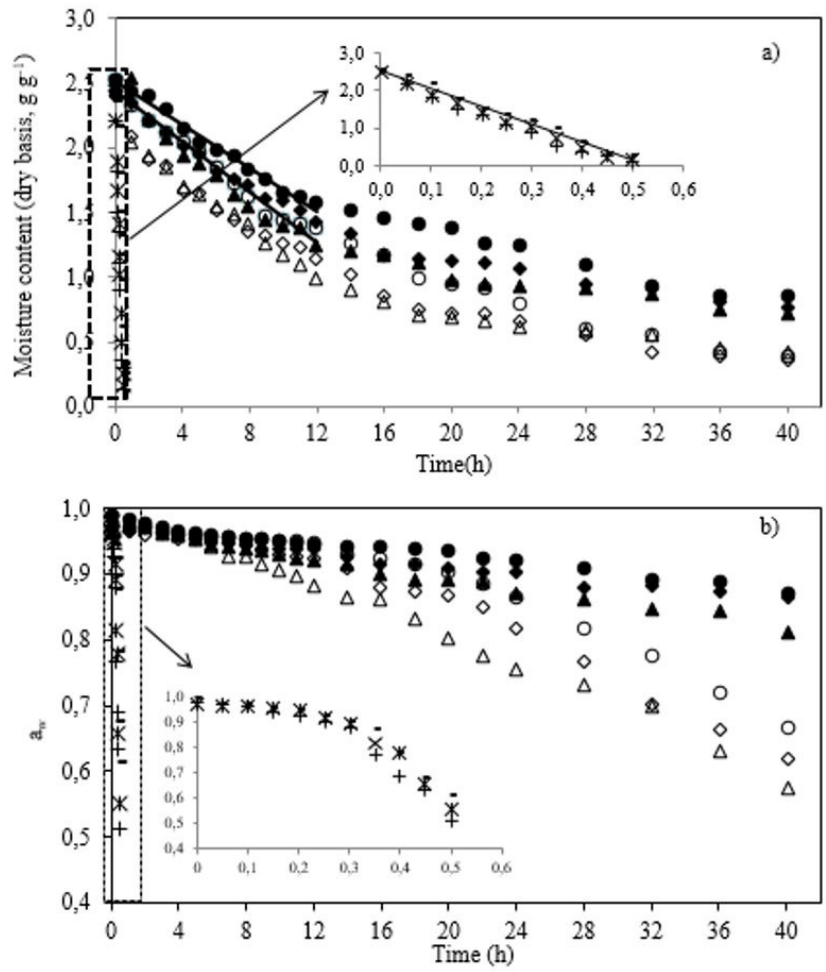

Figure 2. a) Drying curves of beef cuts salted with different saline solutions; b) Evolution of water activity $\left(\mathrm{a}_{\mathrm{w}}\right)$ of the salted samples during drying. (•) Solution A $(100 \% \mathrm{NaCl})+\mathrm{CD}$, (•) Solution $\mathrm{B}(75 \% \mathrm{NaCl}$ and $25 \% \mathrm{KCl})+\mathrm{CD} ;(\boldsymbol{\Delta})$ Solution $\mathrm{C}(50 \% \mathrm{NaCl}$ and $50 \%$ $\mathrm{KCl})+\mathrm{CD},(\mathrm{\circ})$ Solution A +VD, $(\diamond)$ Solution B + VD, $(\Delta)$ Solution C + VD, (-) Solution A + MWVD, ( $\times$ ) Solution B + MWVD, and (+) Solution $\mathrm{C}+$ MWVD. Values shown are means $(\mathrm{n}=3)$.

$\mathrm{CD}$ also convection, which are much slower mechanisms that depend on the physical properties of the material. It is well known that most food products have low thermal diffusivity, which helps to explain the low drying rates of the $\mathrm{CD}$ and $\mathrm{VD}$ methods. The use of different saline solutions with different concentrations of $\mathrm{NaCl}$ and $\mathrm{KCl}$ did not significantly influence $(p<0.05)$ the drying curves. 
The influence of the different drying methods (CD, VD, and MWVD) on the drying rate during the constant-rate period (obtained from the linear fit applied to the drying curves - see Figure 2a) is presented in Table 2. The drying rate of the salted samples using VD was approximately 1.15 times greater than that observed for CD method. Samples subjected to MWVD presented drying rates 56 and 48 times higher than those observed for CD and VD, respectively. Samples salted with Solutions B and $\mathrm{C}$ presented slight higher drying rates when compared to those salted with Solution A, regardless of the drying method.

The variation of the $a_{w}$ of salted samples during drying is shown in Figure 2b. The $a_{w}$ values of CD and VD samples began to differentiate more clearly after $12 \mathrm{~h}$ of process. The $a_{w}$ values of MWVD samples decreased very rapidly (enlarged graph in Figure. $2 \mathrm{~b}$ ), due to the very high drying rate in this process. For samples to reach $a_{w}$ of 0.70 (value found in charque and jerked-beef), 36 hours are necessary in the VD, more than $40 \mathrm{~h}$ in the CD, and only 27 minutes in the MWVD. The differences between $a_{w}$ values of samples treated by the different saline solutions could also be explained by the influence of $\mathrm{K}^{+}$ions, which facilitates

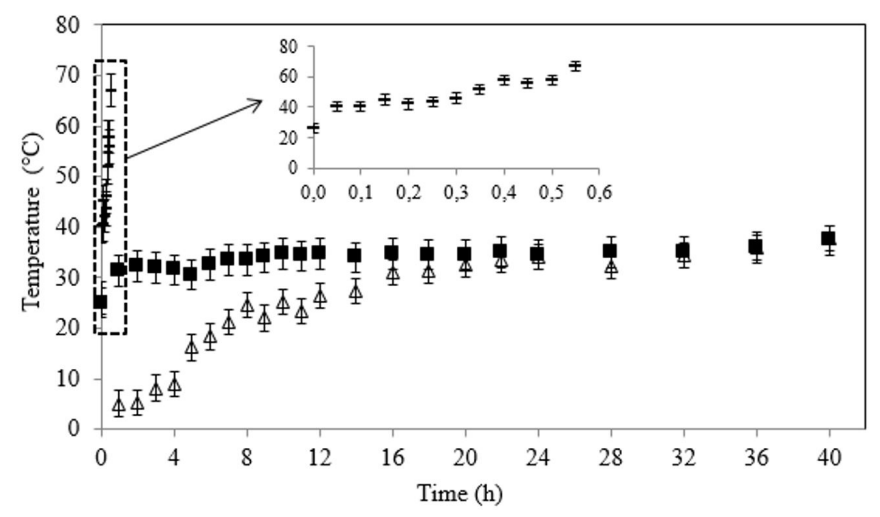

Figure 3. Variation of temperature inside the beef samples during drying. ( $\square$ ) Convective drying - CD, $(\Delta)$ Vacuum drying - VD, and (-) Microwave vacuum drying - MWVD. Values shown are means $(n=9)$.

Table 2. Influence of the saline solution and drying method on the drying rate at constant drying rate period $(n=9)$.

\begin{tabular}{lccc}
\hline Drying method & Solution & $\begin{array}{c}\text { Constant drying } \\
\text { rate }\left(\mathrm{g} \mathrm{H}_{2} \mathrm{O} \mathrm{g}^{-1}\right. \\
\text { of dry solids h}\end{array}$ & $\mathrm{R}^{2}$ \\
\hline \multirow{3}{*}{ CD } & $\mathrm{A}$ & $0.084^{\mathrm{a}}$ & 0.99 \\
& $\mathrm{~B}$ & $0.086^{\mathrm{a}}$ & 0.98 \\
$\mathrm{VD}$ & $\mathrm{C}$ & $0.090^{\mathrm{a}}$ & 0.96 \\
& $\mathrm{~A}$ & $0.097^{\mathrm{b}}$ & 0.98 \\
& $\mathrm{~B}$ & $0.099^{\mathrm{b}}$ & 0.96 \\
MWVD & $\mathrm{C}$ & $0.105^{\mathrm{b}}$ & 0.96 \\
& $\mathrm{~A}$ & $4.737^{\mathrm{c}}$ & 0.99 \\
& $\mathrm{~B}$ & $4.749^{\mathrm{c}}$ & 0.99 \\
\hline
\end{tabular}

CD: convective drying, VD: vacuum drying, MWVD: microwave vacuum drying. Solution A: $100 \% \mathrm{NaCl}$, Solution B: $75 \% \mathrm{NaCl}+25 \% \mathrm{KCl}$, Solution C: $50 \% \mathrm{NaCl}+50 \%$ $\mathrm{KCl} .{ }^{\mathrm{a}-\mathrm{C}} \mathrm{Means}$ in the same column with the same letter do not differ significantly $(\mathrm{p}>0.05)$. water evaporation from the sample, and consequently lead to greater reduction of $a_{w}$.

Figure 3 shows the temperature of the samples during drying. Samples submitted to VD only reached $30^{\circ} \mathrm{C}$ in their centers after 16 hours of drying, while CD and MWVD samples reached the same temperature in the beginning of the process. These results indicate that $\mathrm{VD}$ can be used to preserve thermosensitive foods and to reduce or avoid the formation of a rigid layer that hinders dehydration. The maximum temperature reached inside the samples during $\mathrm{CD}$ and $\mathrm{VD}$ methods was $40^{\circ} \mathrm{C}$. The inner temperature of MWVD samples reached $67^{\circ} \mathrm{C}$, only at the end of the process.

\subsection{Characterization of salted-and-dried beef cuts}

\section{Physicochemical and color parameters}

Average values of moisture, $a_{w} \mathrm{NaCl}$ and $\mathrm{KCl}$ concentrations, as well as the total salt concentration $(\mathrm{NaCl}+\mathrm{KCl})$ of the treated samples are shown in Table 3. The samples dehydrated by VD and MWVD presented higher salt concentration $(\mathrm{NaCl}+\mathrm{KCl})$ than those dehydrated by $\mathrm{CD}$, which is due to the greater moisture reduction caused by the former methods.

Charque and jerked beef typically contain 15 to $20 \mathrm{~g}$ of $\mathrm{NaCl} 100^{-1} \mathrm{~g}$ of sample, $45 \mathrm{~g}$ of $\mathrm{H}_{2} \mathrm{O} 100^{-1} \mathrm{~g}$ of sample, and $a_{w}$ near 0.7 (Shimokomaki et al., 1998). The salted-and-dried meat samples produced in the present study presented total salt concentrations ranging from 6 to $9 \mathrm{~g} 100 \mathrm{~g}^{-1}$. This lower salt concentration is a positive attribute for consumers, but a moisture reduction is crucial to reach products with $a_{w}$ near 0.7 . Because of the dehydration necessary to reach this water activity, each kilogram of product dehydrated by $\mathrm{CD}$ has $570 \mathrm{~g}$ of dry solids. For VD and MWVD the masses of dry solids are $670 \mathrm{~g}$ and $740 \mathrm{~g}$, respectively, regardless of the salt solution used. For the consumer, such a reduced-salt charque is convenient, because it could be used without a desalting step that is time consuming.

The $\mathrm{pH}$ values and color parameters of the salted-and-dried meat are shown in Table 4 . The $\mathrm{pH}$ values of samples dehydrated by CD, VD, and MWVD ranged from 5.7 to 6.1 , which are similar to the values found by Facco (2002) for sun-dried charque. The samples showed a rise of $\mathrm{pH}$ values at the end of the process, for all drying methods evaluated. According to Medyński et al. (2000), this $\mathrm{pH}$ increase is probably caused by the decrease of available protein carboxyl groups, together with the release of calcium and magnesium ions from the proteins caused by the temperature increase.

The values of color parameters $\left(\mathrm{L}^{*}, \mathrm{a}^{*}\right.$ and $\left.\mathrm{b}^{*}\right)$ verified at the surface of dehydrated samples (Table 4 ) are in agreement with the values reported by Facco (2002) and Thiagarajan (2008) for charque and beef jerky, respectively. The color variation $\left(\Delta \mathrm{E}^{\star}\right)$ of dehydrated samples was calculated from salted meat before drying. CD samples showed the highest values of color variation at the surface, for all the three salt solutions evaluated. This result is explained by the higher reduction of parameters $\mathrm{a}^{*}$ and $\mathrm{b}^{*}$ during $\mathrm{CD}$ when compared to the reductions observed for $\mathrm{VD}$ and MWVD samples.

Samples submitted to $\mathrm{CD}$ and VD processes showed decrease of the parameters $L^{*}, a^{*}$ and $b^{*}$ at the end of the dehydration process, whereas samples dehydrated by the MWVD showed 
Table 3. Influence of the saline solution and drying method on the drying time, moisture, $a_{w}$, and salt concentration of the salted-and-dried beef cuts $(\mathrm{n}=9)$.

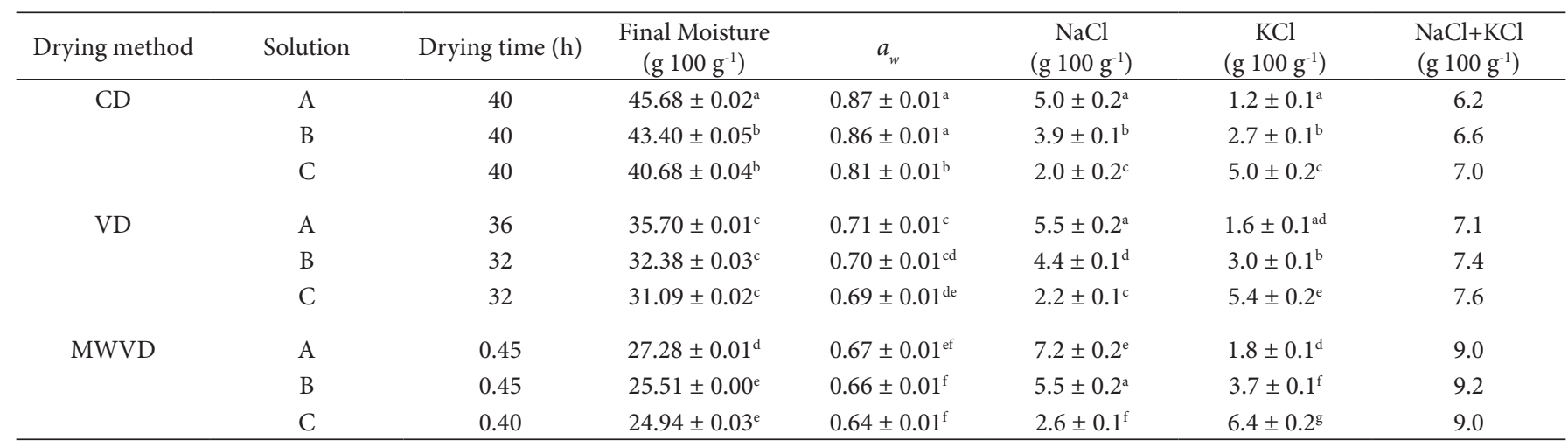

Table 4. Influence of the saline solution and drying method on the $\mathrm{pH}$ values and color parameters of the salted-and-dried beef cuts ( $\mathrm{n}=9$ ).

\begin{tabular}{|c|c|c|c|c|c|c|}
\hline \multirow{2}{*}{ Drying method } & \multirow{2}{*}{ Solution } & \multirow{2}{*}{$\mathrm{pH}$} & \multicolumn{3}{|c|}{ Color parameters } & \multirow{2}{*}{$\Delta \mathrm{E}^{*}$} \\
\hline & & & $\mathrm{L}^{*}$ & $\mathrm{a}^{*}$ & $\mathrm{~b}^{*}$ & \\
\hline \multirow[t]{3}{*}{$\mathrm{CD}$} & $\mathrm{A}$ & $5.9 \pm 0.1^{\mathrm{ab}}$ & $26 \pm 0^{\mathrm{a}}$ & $2.8 \pm 0.4^{\mathrm{a}}$ & $3 \pm 1^{\mathrm{a}}$ & $15.2 \pm 0.4^{\mathrm{a}}$ \\
\hline & B & $5.7 \pm 0.1^{\mathrm{a}}$ & $28 \pm 3^{\text {bcd }}$ & $4 \pm 2^{\mathrm{abc}}$ & $5 \pm 2^{\mathrm{ab}}$ & $12 \pm 4^{\mathrm{ab}}$ \\
\hline & $\mathrm{C}$ & $5.9 \pm 0.1^{\mathrm{ab}}$ & $26 \pm 2^{\mathrm{ab}}$ & $3.5 \pm 0.7^{\mathrm{ac}}$ & $4 \pm 1^{\mathrm{a}}$ & $10 \pm 2^{\mathrm{bc}}$ \\
\hline \multirow[t]{3}{*}{ VD } & A & $5.8 \pm 0.3^{\mathrm{ab}}$ & $26 \pm 2^{\mathrm{ab}}$ & $9 \pm 2^{\text {def }}$ & $7 \pm 3^{\text {cde }}$ & $8 \pm 3^{c}$ \\
\hline & B & $5.8 \pm 0.1^{\mathrm{a}}$ & $28 \pm 2^{\text {abcd }}$ & $5 \pm 1^{\mathrm{abcf}}$ & $5 \pm 2^{\mathrm{ab}}$ & $10 \pm 3^{\mathrm{abc}}$ \\
\hline & $\mathrm{C}$ & $6.1 \pm 0.1^{\mathrm{b}}$ & $28 \pm 1^{\mathrm{abc}}$ & $7.5 \pm 0.7^{\text {abef }}$ & $6 \pm 1^{\text {abe }}$ & $5 \pm 2^{\mathrm{bc}}$ \\
\hline \multirow[t]{3}{*}{ MWVD } & A & $5.8 \pm 0.3^{\mathrm{ab}}$ & $36 \pm 1^{\mathrm{e}}$ & $8.5 \pm 0.3^{\text {bdef }}$ & $13 \pm 1^{\mathrm{cd}}$ & $5.7 \pm 0.1^{\mathrm{c}}$ \\
\hline & B & $5.9 \pm 0.1^{\mathrm{ab}}$ & $34 \pm 4^{\mathrm{e}}$ & $8.6 \pm 0.8^{\text {bdef }}$ & $13 \pm 2^{c}$ & $6 \pm 2^{\mathrm{abc}}$ \\
\hline & $\mathrm{C}$ & $6.0 \pm 0.1^{\mathrm{b}}$ & $34 \pm 3^{\mathrm{e}}$ & $8.4 \pm 0.5^{\text {bef }}$ & $13 \pm 1^{\mathrm{cd}}$ & $6 \pm 2^{\mathrm{bc}}$ \\
\hline
\end{tabular}

CD: convective drying, VD: vacuum drying, MWVD: microwave vacuum drying. Solution A: $100 \% \mathrm{NaCl}$, Solution B: $75 \% \mathrm{NaCl}+25 \% \mathrm{KCl}, \mathrm{Solution} \mathrm{C:} 50 \% \mathrm{NaCl}+50 \% \mathrm{KCl} .{ }^{\text {a-f }} \mathrm{Means}$ in the same column with the same letter do not differ significantly ( $\mathrm{p}>0.05)$. Note: CIELAB coordinate system: $\mathrm{L}^{*}$ (whiteness/darkness), $\mathrm{a}^{*}$ (greenness/redness), $\mathrm{b}^{\star}$ (blueness/yellowness).

increase of $\mathrm{L}^{\star}$ and $\mathrm{b}^{\star}$. During $\mathrm{CD}$, the meat samples remained at $40^{\circ} \mathrm{C}$ for a long period in the presence of oxygen, while during VD and MWVD the available oxygen is reduced. As discussed before, MWVD is a very fast drying process, when compared to $\mathrm{CD}$ and VD, but the sample temperatures are higher. The relative importance of time and temperature on the changes of color and other food properties is a complex problem that deserves a specific study about many reactions kinetics. For example, the temperature increase during drying may cause changes of color parameters due to: (i) the formation of denatured methemoglobin (favored by low oxygen pressure, high temperatures, and presence of salt) of brown color and (ii) darkening reaction due to the carbohydrate caramelization and Maillard reaction.

\section{Accessible porosity}

The accessible porosities of fresh and salted-and-dried meat samples are described in Table 5. The porosities of salted samples were 1.7 to 2.2 times greater than those of fresh meat, which is attributed to the osmotic dehydration caused by the saline solutions that increases the empty spaces in the samples (intercellular spaces). The results also showed that samples from a same drying process had similar accessible porosity, indicating that the salting procedure had no influence in this property. However, the accessible porosity of dried samples was influenced by the drying method. The porosities of samples dehydrated by VD and MWVD were approximately 2 and 3 times larger,
Table 5. Porosity and rehydration capacity $(\mathrm{RC})$ of salted-and-dried beef cuts $(n=9)$.

\begin{tabular}{cccc}
\hline Sample & Solution & Porosity $(\%)$ & RC (\%) \\
\hline Fresh & & $3 \pm 1^{\mathrm{a}}$ & \\
& A & $9 \pm 2^{\mathrm{b}}$ & $43 \pm 4^{\mathrm{a}}$ \\
CD & B & $12 \pm 1^{\mathrm{b}}$ & $39 \pm 8^{\mathrm{a}}$ \\
& C & $12 \pm 1^{\mathrm{b}}$ & $36 \pm 1^{\mathrm{a}}$ \\
VD & A & $19 \pm 3^{\mathrm{c}}$ & $45 \pm 8^{\mathrm{a}}$ \\
& B & $22 \pm 2^{\mathrm{c}}$ & $69 \pm 1^{\mathrm{b}}$ \\
& C & $25 \pm 2^{\mathrm{c}}$ & $79 \pm 10^{\mathrm{b}}$ \\
MWVD & A & $28 \pm 3^{\mathrm{cd}}$ & $69 \pm 6^{\mathrm{b}}$ \\
& B & $31 \pm 4^{\mathrm{d}}$ & $73 \pm 8^{\mathrm{b}}$ \\
& C & $34 \pm 4^{\mathrm{d}}$ & $101 \pm 9^{\mathrm{c}}$ \\
\hline
\end{tabular}

CD: convective drying, VD: vacuum drying, MWVD: microwave vacuum drying. Solution A: $100 \% \mathrm{NaCl}$, Solution B: $75 \% \mathrm{NaCl}+25 \% \mathrm{KCl}$, Solution C: $50 \% \mathrm{NaCl}+50 \%$ $\mathrm{KCl} .{ }^{\mathrm{a}-\mathrm{d}}$ Means in the same column with the same letter do not differ significantly $(\mathrm{p}>0.05)$.

respectively, than the porosity of CD samples. This difference was visually perceptible, as one can notice from Figure 4. Porosity of dried foods depends on the shrinkage during drying. During CD, the liquid present in the porous structure generates tensions in the solid matrix that are mainly due to changes in the capillary pressure of the system. The natural reaction of the solid matrix to such a condition produces shrinkage, which reduces the stress condition and leads to changes in the porous space. In this 
way, porosity formation during drying depends on both, water evaporation and creation of the porous space. Low drying rates during $\mathrm{CD}$ facilitate the accommodation of the cellular matrix to the tensions created by water evaporation; this explains the higher shrinkage and lower porosity of samples subjected to this drying method (Porciuncula et al., 2015). If the volume reduction (shrinkage) is strictly proportional to the mass loss, shrinkage could be considered ideal. However, if the volume reduction is less than the volume of water evaporated during drying, this indicates lower shrinkage that leads to higher food porosity.

The higher porosity of samples dehydrated by MWVD could be explained by the fast evaporation of water during drying, caused by the quick heating that leads to a quick evaporation under vacuum. The expanding air-vapor mixture tends to reduce the solid shrinkage possibly occurring in some internal regions. The shrinkage is balanced by the creation of larger pores. During rapid evaporation, capillary pressure that tends to produce shrinkage competes with gas expansion that tends to open the porous matrix.

\section{Scanning electron micrographs}

Figure 5 shows scanning electron micrographs (magnification of 50 and 250 times) of a fresh beef sample (Figure 5a), a beef sample after salting using Solution A (Figure $5 b$ ), and beef samples after salting and drying by CD (Figure 5c), VD (Figure 5d), and MWVD (Figure 5e). In Figure 5a it is possible to observe the fiber bundles of fresh meat, which are parallel and close to each other, whereas the micrographs of salted meat (Figure. 5b) show a slight spacing between the bundles of fibers. This difference can be attributed to dehydration during salting. From Figures 5c, 5d, and 5e, one can observe more spaced fiber bundles, whose importance depends on the drying method. MWVD samples tend to have more spaced fiber bundles if compared to those submitted to other drying methods. Moreover, fiber bundles of VD samples tend to be more spaced than those of CD samples. The greater distance of the fiber bundles is attributed to higher dehydration rates, which increased sample volume. These results corroborate the results of accessible porosity.

\section{Rehydration capacity}

In general, the rehydration capacity (RC) of samples submitted to MWVD was 50\% higher than that observed for CD samples and $20 \%$ higher than that observed for VD samples (see Table 5). Samples salted with Solutions B and C and dried by VD and MWVD presented higher RC than CD samples, which

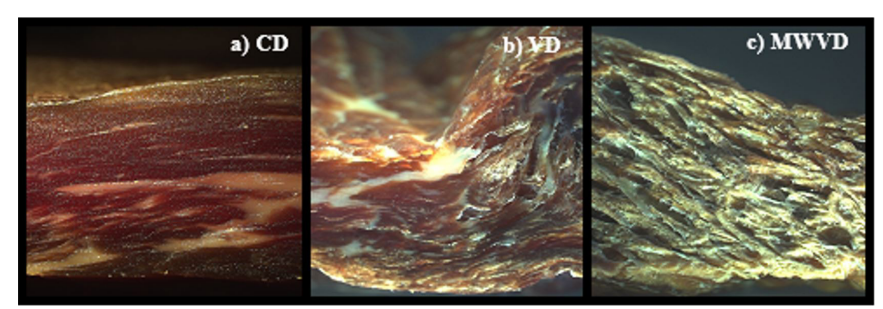

Figure 4. Pictures of salted beef cuts (using Solution A) submitted to different drying methods. a) Convective drying (CD), b) Vacuum drying (VD), and c) Microwave vacuum drying (MWVD). can be attributed to the higher water loss and higher porosity of samples salted with Solutions B and C.

\section{Mechanical properties}

The mechanical properties of the salted-and-dried beef samples are described in Table 6. The values of the WB shear force observed for samples salted with Solutions B and C were
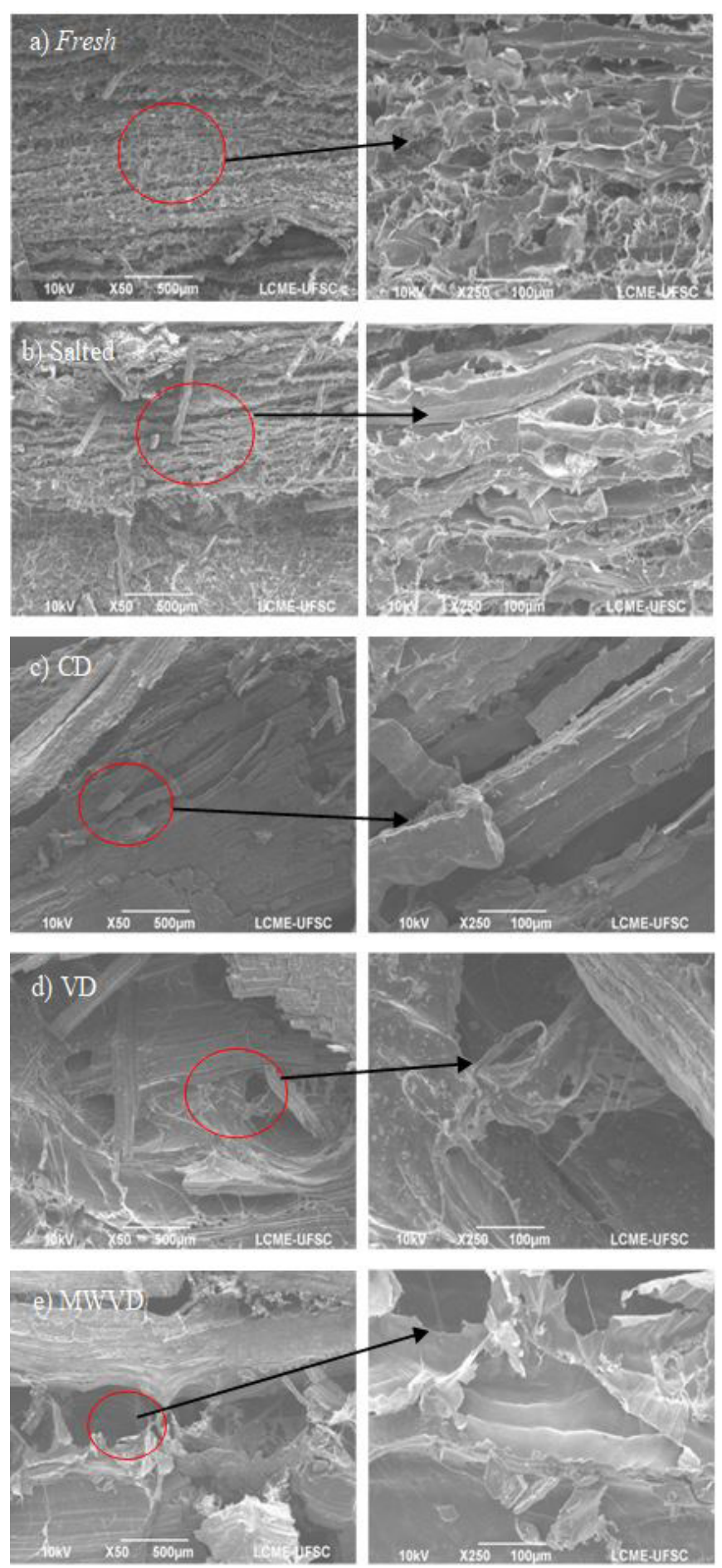

Figure 5. Scanning electron micrographs of beef samples (magnification of 50 and 250 times). a) fresh, b) after salting, c) after drying by CD, d) after drying by VD, and e) after drying by MWVD. 
Table 6. Influence of saline solution and drying method on the mechanical properties of the salted-and-dried beef cuts $(n=9)$.

\begin{tabular}{|c|c|c|c|c|c|c|c|}
\hline \multirow{2}{*}{ Drying method } & \multirow{2}{*}{ Solution } & WB shear force & $\mathrm{H}$ & \multirow{2}{*}{ Co } & \multirow{2}{*}{ S } & $\mathrm{G}$ & $\mathrm{Ch}$ \\
\hline & & $(\mathrm{N})$ & $(\mathrm{N})$ & & & $(\mathrm{N})$ & $(\mathrm{N})$ \\
\hline \multirow[t]{3}{*}{$\mathrm{CD}$} & $\mathrm{A}$ & $117 \pm 18^{\mathrm{a}}$ & $132 \pm 14^{\text {ae }}$ & $0.45 \pm 0.07^{\mathrm{a}}$ & $0.7 \pm 0.2^{\mathrm{a}}$ & $60 \pm 17^{\mathrm{a}}$ & $38 \pm 17^{\mathrm{a}}$ \\
\hline & B & $241 \pm 15^{\mathrm{bc}}$ & $332 \pm 15^{\mathrm{b}}$ & $0.50 \pm 0.03^{\mathrm{abc}}$ & $0.6 \pm 0.2^{\mathrm{a}}$ & $158 \pm 15^{\mathrm{b}}$ & $96 \pm 14^{b c}$ \\
\hline & $\mathrm{C}$ & $287 \pm 18^{c}$ & $301 \pm 18^{\mathrm{bc}}$ & $0.48 \pm 0.06^{\mathrm{ab}}$ & $0.6 \pm 0.2^{\mathrm{a}}$ & $150 \pm 17^{\mathrm{b}}$ & $92 \pm 17^{\mathrm{bc}}$ \\
\hline \multirow[t]{3}{*}{$\mathrm{VD}$} & A & $135 \pm 14^{\mathrm{ad}}$ & $103 \pm 15^{\mathrm{a}}$ & $0.47 \pm 0.12^{\mathrm{ab}}$ & $0.7 \pm 0.2^{\mathrm{a}}$ & $58 \pm 16^{\mathrm{a}}$ & $43 \pm 16^{\mathrm{a}}$ \\
\hline & B & $252 \pm 18^{\mathrm{bc}}$ & $272 \pm 19^{b c}$ & $0.48 \pm 0.05^{\mathrm{ab}}$ & $0.7 \pm 0.2^{\mathrm{a}}$ & $132 \pm 19^{b c}$ & $78 \pm 18^{\mathrm{ab}}$ \\
\hline & $\mathrm{C}$ & $211 \pm 14^{\text {be }}$ & $243 \pm 17^{\mathrm{cd}}$ & $0.50 \pm 0.05^{\mathrm{abc}}$ & $0.7 \pm 0.2^{\mathrm{a}}$ & $123 \pm 16^{\mathrm{bc}}$ & $70 \pm 16^{\mathrm{ab}}$ \\
\hline \multirow[t]{3}{*}{ MWVD } & A & $155 \pm 19^{\mathrm{ad}}$ & $147 \pm 13^{\mathrm{e}}$ & $0.74 \pm 0.05^{\mathrm{d}}$ & $0.7 \pm 0.0^{\mathrm{a}}$ & $95 \pm 17^{\mathrm{ab}}$ & $46 \pm 16^{\mathrm{ab}}$ \\
\hline & B & $238 \pm 17^{\mathrm{bc}}$ & $249 \pm 13^{\mathrm{cd}}$ & $0.71 \pm 0.11^{\mathrm{cd}}$ & $0.8 \pm 0.2^{\mathrm{a}}$ & $164 \pm 16^{c}$ & $125 \pm 16^{c}$ \\
\hline & $\mathrm{C}$ & $227 \pm 19^{\text {be }}$ & $228 \pm 16^{\mathrm{d}}$ & $0.68 \pm 0.11^{\mathrm{bcd}}$ & $0.7 \pm 0.2^{\mathrm{a}}$ & $156 \pm 15^{\mathrm{c}}$ & $106 \pm 19^{b c}$ \\
\hline
\end{tabular}

significantly higher $(\mathrm{p}<0.05)$ than those observed for samples salted with Solution A, for the three drying methods evaluated. A similar tendency was observed for the hardness, gumminess, and chewiness parameters. Samples dehydrated by MWVD presented significantly higher $(\mathrm{p}<0.05)$ values for the cohesion parameter than those dehydrated by $\mathrm{CD}$ and VD, for three saline solutions used. On the other hand, the values of springiness were independent of the salting and drying processes $(\mathrm{p}>0.05)$.

\section{Conclusion}

The results presented in this study have technological importance for the design of new industrial technologies to produce salted-and-dried-meat, such as charque and jerked-beef. Microwave vacuum drying can dehydrate salted meat in a significantly short time as compared to convective drying and vacuum drying. The salted beef dried by microwave under vacuum also presents higher values of porosity and, consequently, a higher rehydration capacity than salted beef dried by CD and VD. Moreover, it is possible: (i) to reduce the $\mathrm{NaCl}$ content of the product using $\mathrm{KCl}$ as a partial replacement without affecting considerably the physicochemical and mechanical properties of the salted-and-dried beef cuts; and (ii) to reduce the total salt content (at the cost of a higher moisture reduction), allowing to obtain a salted-and-dried product more convenient for consumers since desalting may not be necessary before consumption. A detailed study regarding the impact of salt and moisture reduction on the sensory properties, and also on the chemical and microbiological stability of this new salted-and-dried meat must be evaluated.

\section{Acknowledgements}

The authors are grateful to CAPES/Brasil and the CNPq/ Brasil for financial support.

\section{References}

Albarracín, W., Sánchez, I. C., Grau, R., \& Barat, J. M. (2011). Salt in food processing, usage and reduction: a review. International Journal of Food Science \& Technology, 46(7), 1329-1336. http:// dx.doi.org/10.1111/j.1365-2621.2010.02492.x.

Aliño, M., Grau, R., Toldrá, F., \& Barat, J. M. (2010). Physicochemical changes in dry-cured hams salted with potassium, calcium and magnesium chloride as a partial replacement for sodium chloride. Meat Science, 86(2), 331-336. http://dx.doi.org/10.1016/j. meatsci.2010.05.003. PMid:20541872.
Arnau, J., Serra, X., Comaposada, J., Gou, P., \& Garriga, M. (2007). Technologies to shorten the drying period of dry-cured meat products. Meat Science, 77(1), 81-89. http://dx.doi.org/10.1016/j. meatsci.2007.03.015. PMid:22061398.

Association of Official Analytical Chemists - AOAC. (2007). Official methods of analysis (18th ed.). Washington: AOAC.

Bampi, M., Domschke, N. N., Schmidt, F. C., \& Laurindo, J. B. (2016b). Influence of vacuum application, acid addition and partial replacement of $\mathrm{NaCl}$ by $\mathrm{KCl}$ on the mass transfer during salting of beef cuts. Lebensmittel-Wissenschaft + Technologie, 74, 26-33. http://dx.doi. org/10.1016/j.lwt.2016.07.009.

Bampi, M., Sereno, A. M., Schmidt, F. C., \& Laurindo, J. B. (2016a). Evaluation of different software tools for deconvolving differential scanning calorimetry thermograms of salted beef. Food Science and Technology (Campinas), 36(4), 694-700. http://dx.doi.org/10.1590/1678457x.10016.

Barat, J. M., Baigts, D., Aliño, M., Fernández, F. J., \& Pérez-García, V. M. (2011). Kinetics studies during $\mathrm{NaCl}$ and $\mathrm{KCl}$ pork meat brining. Journal of Food Engineering, 106(1), 102-110. http://dx.doi. org/10.1016/j.jfoodeng.2011.04.022.

Barat, J. M., Pérez-Esteve, E., Aristoy, M. C., \& Toldrá, F. (2012). Partial replacement of sodium in meat and fish products by using magnesium salts. A review. Plant and Soil, 368(1-2), 179-188. http:// dx.doi.org/10.1007/s11104-012-1461-7.

Brasil. Ministério da Agricultura, Pecuária e Abastecimento. (2000, Julho 31). Anexo II - Regulamento Técnico de Identidade e Qualidade de Carne Bovina Salgada Curada Dessecada ou Jerked Beef (Instrução Normativa no 22, de 31 de julho de 2000). Brasília.

Chen, X. D., \& Mujumdar, A. S. (2008). Drying Technologies in Food Processing (p. 322). Chennai: Blackwell Publishing.

Collignan, A., Bohuon, P., Deumier, F., \& Poligné, I. (2001). Osmotic treatment of fish and meat products. Journal of Food Engineering, 49(2-3), 153-162. http://dx.doi.org/10.1016/S0260-8774(00)00215-6.

Facco, E. M. P. (2002). Parameters of charque quality related to the effect of vitamin $E$ supplementation on the diet of Nellore cattle in confinement (M.Sc. thesis). Universidade Estadual de Campinas, Campinas. p. 100.

Foerst, P., \& Kulozik, U. (2007). Validation of a novel in situ weighing system during vacuum drying. Drying Technology, 25(5), 767-773. http://dx.doi.org/10.1080/07373930701370142.

Haghi, A. K., \& Amanifard, N. (2008). Analysis of heat and mass transfer during microwave drying of food products. Brazilian Journal of Chemical Engineering, 25(3), 491-501. http://dx.doi.org/10.1590/ S0104-66322008000300007. 
Huidobro, F. R., Miguel, E., Blázquez, B., \& Onega, E. (2005). A comparison between two methods (Warner-Bratzler and texture profile analysis) for testing either raw meat or cooked meat. Meat Science, 69(3), 527-536. http://dx.doi.org/10.1016/j.meatsci.2004.09.008. PMid:22062992.

Instituto Adolfo Lutz - IAL. (2008). Normas analíticas do Instituto Adolfo Lutz: Métodos químicos e físicos para análise de alimentos (4th ed.). São Paulo: IMESP.

Jangam S. V., Law C.L. \& Mujumdar A. S. (2010). Drying of foods, vegetables and fruits (Vol. 1, p. 202) Singapore: TPR Grou.

Jangam, S. V. (2011). An overview of recent developments and some R\&D challenges related to drying of foods. Drying Technology, 29(12), 1343-1357. http://dx.doi.org/10.1080/07373937.2011.594378.

Lozano, J. E., Rotstein, E., \& Urbicain, M. J. (1983). Shrinkage, porosity and bulk density of foodstuffs at changing moisture contents. Journal of Food Science, 48(5), 1497-1553. http://dx.doi. org/10.1111/j.1365-2621.1983.tb03524.x.

Manafzadeh, A., Emam-Djomeh, Z., \& Fadae, I. V. (2013). Investigation on the drying effects on nutritional attributes of dried lamb meat. International Journal of Recent Scientific Research, 4, 987-991.

Mcgough, M. M., Sato, T., Rankin, S. A., \& Sindelar, J. J. (2012). Reducing sodium levels in frankfurters using naturally brewed soy sauce. Meat Science, 91(1), 69-78.

Medyński, A., Pospiech, E., \& Kniat, R. (2000). Effect of various concentrations of lactic acid and sodium chloride on selected physico-chemical meat traits. Meat Science, 55(3), 285-290. http:// dx.doi.org/10.1016/S0309-1740(99)00153-9. PMid:22061284.

Monteiro, R. L., Carciofi, B. A. M., Marsaioli, A. Jr, \& Laurindo, J. B. (2015). How to make a microwave vacuum dryer with turntable. Journal of Food Engineering, 166, 276-284. http://dx.doi.org/10.1016/j. jfoodeng.2015.06.029.

Muñoz, I., Garcia-Gil, N., Arnau, J., \& Gou, P. (2012). Rehydration kinetics at 5 and $15^{\circ} \mathrm{C}$ of dry salted meat. Journal of Food Engineering, 110(3), 465-471. http://dx.doi.org/10.1016/j.jfoodeng.2011.12.020.
Nathakaranakule, A., Kraiwanichkul, W., \& Soponronnarit, S. (2007). Comparative study of different combined superheated-steam drying techniques for chicken meat. Journal of Food Engineering, 80(4), 1023-1030. http://dx.doi.org/10.1016/j.jfoodeng.2006.04.067.

Ojha, K. S., Kerry, J. P., \& Tiwari, B. K. (2017). Investigating the influence of ultrasound pre-treatment on drying kinetics and moisture migration measurement in Lactobacillus sakei cultured and uncultured beef jerky. Lebensmittel-Wissenschaft + Technologie, 81, 42-49. http:// dx.doi.org/10.1016/j.lwt.2017.03.011.

Porciuncula, B. D. A., Segura, L. A., \& Laurindo, J. B. (2015). Processes for controlling the structure and texture of dehydrated banana. Drying Technology, 80, 1023-1030. http://dx.doi.org/10.1080/073 73937.2015.1014911.

Ratti, C. (2001). Hot air and freeze-drying of high-value food: a review. Journal of Food Engineering, 49(4), 311-319. http://dx.doi.org/10.1016/ S0260-8774(00)00228-4.

Schmidt, F. C., Aragão, G. M. F., \& Laurindo, J. B. (2010). Integrated cooking and vacuum cooling of chicken breast cuts in a single vessel. Journal of Food Engineering, 100(2), 219-224. http://dx.doi. org/10.1016/j.jfoodeng.2010.04.002.

Sereno, A. M., Silva, M. A., \& Mayor, L. (2007). Determination of particle density and porosity in foods and porous materials with high moisture content. International Journal of Food Properties, 10(3), 455-469. http://dx.doi.org/10.1080/10942910600880736.

Shimokomaki, M., Franco, B. D. G. M., Biscontini, T. M., Pinto, M. F., Terra, N. N., \& Zorn, T. M. T. (1998). Charqui meats are hurdle technology meat products. Food Reviews International, 14(4), 339349. http://dx.doi.org/10.1080/87559129809541167.

Thiagarajan, I. V. (2008). Combined microwave-convection drying and textural characteristics of beef jerky. (M.Sc. thesis). University of Saskatchewan, Saskatoon.

Toldrá, F. (2016). Dry-Cured Meats. In G. W. Smithers (Ed.), Reference Module in Food Science. Amsterdam: Elsevier. http://dx.doi. org/10.1016/B978-0-08-100596-5.03014-6. 